\title{
Perancangan Aplikasi Point of Sale dengan Arsitektur Client/Server Berbasis Linux dan Windows
}

\author{
Sandy Kosasi \\ Program Studi Sistem Informasi STMIK Pontianak, Jl. Merdeka No. 372 Pontianak \\ E-mail: $\underline{\text { sandykosasi@ stmikpontianak.ac.id }}$
}

\begin{abstract}
Abstrak
Perancangan sistem aplikasi point of sale (POS) dapat memberikan pelayanan yang lebih baik kepada konsumen, seperti dalam perhitungan harga dan jumlah barang yang dibeli dapat menjadi lebih cepat dan kuantitas barang tidak lagi bergantung kepada pencatatan manual. Penelitian menghasilkan aplikasi POS menggunakan arsitektur client/server yang terintegrasi antar proses bisnis untuk bagian penjualan, kasir dan gudang. Pengembangan arsitektur client/server ini menggunakan sistem operasi Linux distro Redhat 9 dan Windows Xp Profesional. Penelitian ini menggunakan metode research and development dengan teknik pengumpulan data berupa observasi, wawancara, daftar pertanyaan. Perancangan aplikasi menggunakan menggunakan diagram use case, activity, sequence dan class. Hasil penelitian meliputi modul aplikasi kasir (front office), modul aplikasi gudang dan modul aplikasi laporan (back office). Modul aplikasi antara lain mencakup pengelolaan penjualan, edit data penjualan, pengisian data barang, penentuan harga barang, dan menghasilkan laporan penjualan.
\end{abstract}

Kata Kunci - aplikasi point of sale, metode research and development, arsitektur client/server

\begin{abstract}
Point of sale (POS) application system design can give better service to the consumer, example in the price count and sum of item purchased can become faster and quantity of the item no longer rely on the manual recording. As for the research purpose is create integrated point of sale application using client/server architecture between business process to the warehouse, sales and cashier. The development of client/server architecture is using Linux operating system with distro Redhat 9.0 and windows Xp profesional. Experiment is using research and development method with technique to gather data are observation, interview, question list. This application design is using use case, activity, sequence and class diagram. The research instrument consist of cashier application (front office), warehouse application module and report application module (back office). Application module like sales management, sales data edit, equipment data insertion, pricing of the goods and generate sales report.
\end{abstract}

Keywords - Point of sale application, research and development method, client/server architecture

\section{PENDAHULUAN}

Sistem aplikasi point of sale (POS) merupakan aplikasi untuk mengelola transaksi bisnis ritel swalayan yang berhubungan dengan pengolahan data transaksi pembelian, transaksi penjualan eceran, dan pelaporan transaksi bagi pihak manajemen. Suatu sistem perangkat lunak untuk mengelola penjualan barang secara ritel. Aplikasi POS memungkinkan transaksi di dalamnya diproses lebih cepat juga efisien dalam mengelola sistem dan tingkat persediaan barang ritel [1]. Sebagai bentuk usaha yang bergerak di bidang penjualan retail untuk berbagai macam kebutuhan sehari-hari jelas membutuhkan akselerasi penanganan transaksi secara cepat. 
Memiliki integrasi sistem antara gudang dan penjualan merupakan faktor yang sangat penting. Hal ini juga menjadi persoalan yang terjadi pada minimarket Citra Niaga. Segala proses transaksi ritel masih menggunakan sistem manual dengan alat bantu cash register. Mesin register kas ini memiliki banyak keterbatasan dari sisi jumlah item barang, proses pengolahan data transaksi dan informasi yang dapat dihasilkan masih terbatas seperti hanya pendapatan harian saja, belum memiliki informasi lengkap mengenai semua barang yang telah terjual, belum ada integrasi informasi bagian penjualan dengan gudang secara langsung sehingga sulit melakukan pengecekan stok barang. Kenyataan ini menyebabkan tidak adanya jaminan kehandalan dan validitasi informasi bagi pihak manajemen dan konsumen.

Kenyataan ini jelas merupakan persoalan yang sangat serius dan memerlukan cara penyelesaian yang tepat untuk memperbaiki kondisi yang ada di minimarket Citra Niaga agar dapat meningkatkan kinerja dan daya saingnya dengan sejumlah kompetitor. Tidak hanya untuk mempertahankan pelanggan yang sudah ada, namun yang paling penting adalah mencegah beralihnya pelanggan ke kompetitor lain. Kebutuhan ini jelas merupakan faktor yang sangat esensial dan perlu segera diantisipasi dengan membangun sebuah aplikasi POS yang memiliki integrasi informasi pengolahan data transaksi, kasir dan penyimpanan barang dalam gudang menggunakan arsitektur client/server. Arsitektur client/server dirancang untuk memisah layanan basis data dari client, dengan penghubungnya menggunakan jalur komunikasi data [2]. Layanan basis data diimplementasikan pada sebuah komputer yang berdaya guna, yang memungkinkan manajemen tersentralisasi, keamanan, dan berbagai sumber daya [2,3].

Aplikasi yang baik harus memperhatikan user interface dan memiliki kemampuan berinteraksi dengan database secara paralel [3]. User interface merupakan faktor penting agar pemakai sistem dapat menggunakannya dengan mudah dan cepat. Pemberian nama harus jelas dan penggunaan istilah yang sesuai kebutuhan [4]. Melalui aplikasi ini diharapkan dapat mempermudah saat melakukan proses transaksi dengan sistem barcode, penanganan bukti-bukti transaksi, mempermudah melakukan update harga barang, pengecekan stok barang, dan penanganan persediaan dan proses mutasi barang menjadi lebih akurat dan yang jelas dapat meningkatkan sistem pelayanan kepada pelanggan dan masyarakat.

Penelitian sejenis yang dilakukan sebelumnya menggunakan bahasa pemrograman c\# dengan teknologi .Net Framework dengan database MS Office Access 2003 dan masih bersifat semi integrasi antar proses bisnis [5]. Selain itu fitur-fitur aplikasi yang dihasilkan masih terbatas hanya untuk pengolahan data transaksi saja dan dengan informasi yang terbatas $[5,6]$. Merujuk penelitian yang sudah dilakukan sebelumnya, dalam penelitian ini menggunakan VB .net dengan database MySQL dan menggunakan arsitektur client/server berbasis Linux dan Windows[3,4,5]. Hasil dari aplikasi ini memiliki sejumlah fitur-fitur lain yang dapat menyelaraskan sesuai kebutuhan bagi pihak manajemen minimarket melalui arsitektur client/server dalam menghadapi para kompetitor sebagai suatu bentuk daya saing saat ini dan mendatang.

\section{METODE PENELITIAN}

Kegiatan dan cara penelitian ini menggunakan metode research and development. Metode perancangan mencakup requirements analysis and definition, system and software design, implementation and unit testing, integration and system testing, operation and maintenance. Teknik pengumpulan data menggunakan wawancara, observasi, dan penyebaran angket daftar pertanyaan ke sejumlah responden dengan pendekatan purposive sampling. Adapun aspek penelitian meliputi modul aplikasi kasir, aplikasi penjualan, dan aplikasi inventori untuk penanganan penyimpanan barang di gudang. Fokus aplikasi mencakup pengelolaan transaksi penjualan, update data penjualan, pengisian data barang, penentuan harga barang, dan pembuatan laporan dari sejumlah informasi yang menjadi kebutuhan pihak manajemen. Sementara pemodelan aplikasinya menggunakan diagram use case, diagram activity, diagram sequence dan diagram class. 


\section{HASIL DAN PEMBAHASAN}

Untuk mempermudah pemahaman kebutuhan dari perancangan aplikasi sistem point of sale (POS), maka dibagi ke dalam dua jenis kebutuhan yaitu kebutuhan fungsional dan kebutuhan nonfungsional. Kebutuhan fungsional merupakan kebutuhan yang berisi prosesproses apa saja yang nantinya dilakukan oleh sistem saat digunakan. Sementara kebutuhan nonfungsional merupakan kebutuhan yang menitikberatkan kepada properti prilaku yang dimiliki oleh sistem dan pengguna. Aplikasi minimarket dibangun ke dalam 2 (dua) modul utama yaitu modul kasir dan penjualan dan modul inventori untuk gudang. Untuk mempermudah memahami model arsitektur client/server dari sistem yang dikembangkan, maka perlu memahami arsitekturnya.

Memahami arsitektur ini sangat penting agar dalam penerapannya menjadi lancar dan mudah. Seperti dalam arsitektur tradisional, fokusnya adalah benar pada pengguna dan kebutuhan pengguna. Hal ini memerlukan perhatian khusus pada aplikasi, rencana bisnis, kegunaan, desain interaksi, informasi dan desain arsitektur aplikasi. Model arsitektur ini mendeskripsikan rancangan dari perangkat lunak server dan komputer client. Perancangan arsitektur ini akan mempresentasikan framework dari sistem perangkat lunak yang dikembangkan. Deskripsi arsitektur ini mengadopsi spesifikasi sistem, model analisis, dan interaksi subsistem yang telah didefinisikan dalam tahap analisis. Arsitektur pengembangan aplikasi minimarket yang diusulkan diperlihatkan pada gambar 1 .

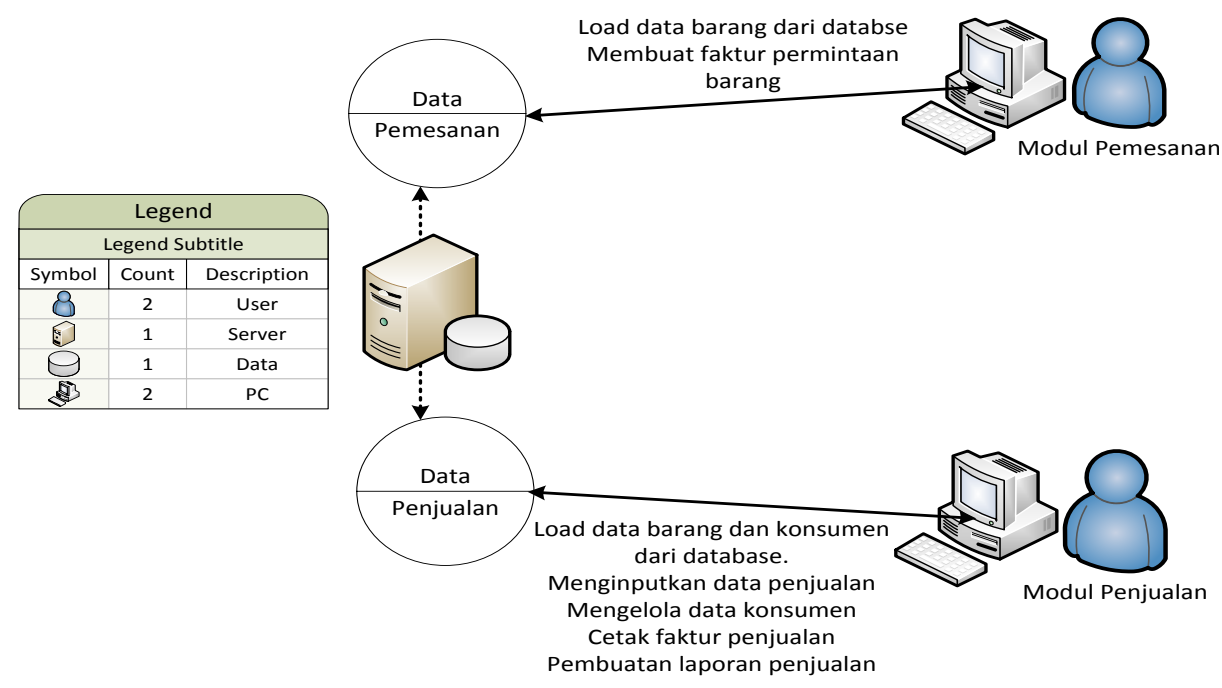

Gambar 1. Arsitektur Aplikasi Client/Server

\begin{tabular}{|c|c|c|}
\hline \multicolumn{3}{|c|}{ Legend } \\
\hline \multicolumn{3}{|c|}{ Legend Subtitle } \\
\hline Symbol & Count & Description \\
\hline$\$$ & 1 & Switch \\
\hline 0 & 1 & $\begin{array}{c}\text { Database } \\
\text { server }\end{array}$ \\
\hline 8 & 2 & Printer \\
\hline
\end{tabular}

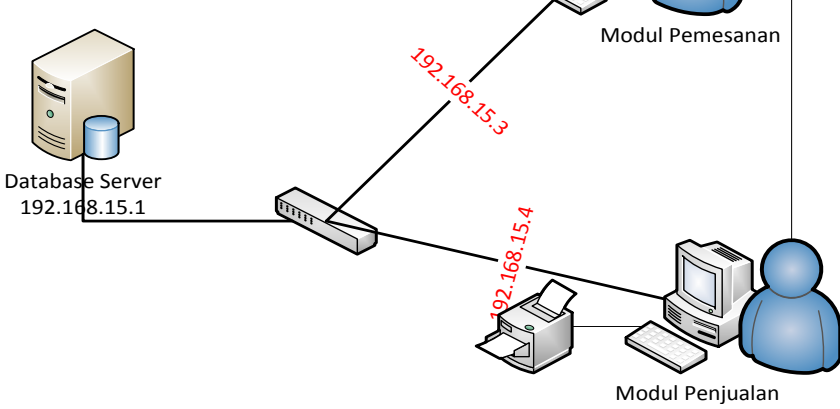

Gambar 2. Arsitektur Local Area Network 
Perancangan arsitektur client/server dimaksudkan untuk memberikan gambaran dari kebutuhan perangkat keras jaringan dan model dari arsitektur jaringan yang harus disiapkan perusahaan. Dalam gambar 2, dapat dilihat arsitektur jaringan local area network (LAN) yang akan dibangun perusahaan. Melalui LAN yang diusulkan dapat menjadikan aplikasi POS melakukan fungsinya untuk mempermudah dalam pemeliharaan dan pendistribusian informasi untuk semua unit kerja dan proses bisnis yang berhubungan satu dengan lainnya. Strategi dalam tahapan perancangan aplikasi POS mengacu kepada perancangan berbasis obyek sehingga pengaksesan database menjadi lebih mudah dan cepat. Arsitektur client/server memiliki sebuah Server untuk mengatur akses resource (file dan print) untuk Workstation. Server menjalankan Network Operating System (NOS) untk menyediakan layanan dan mengotentifikasi Workstation/user dan client menjalankan software NOS-Client. Server bisa berbentuk dedicated yang berfungsi hanya sebagai Server, contohnya Server Novell NetWare, ada juga yang mempunyai dua fungsi sekaligus bisa dipakai sebagai layaknya sebuah Workstation. NOS yang non-dedicated lebih banyak disukai pengguna, contoh yang non-dedicated adalah Windows NT Server dan hampir semua mesin Unix dan Linux. Melalui arsitektur client/server perangkat keras dan perangkat lunak bisa ditempatkan di mana saja sehingga bisa bekerja secara lebih optimal. Arsitektur client/server juga dapat melakukan proses balancing (penyebaran), yaitu proses yang mencegah suatu prosesor mengalami overload (terbeban) sementara mesin lainnya justru menganggur. Dapat mengoptimalkan penggunaan sumberdaya secara lebih efisien, penyimpanan data terpusat, serta lalu lintas di dalam jaringan menjadi lebih rendah (dibandingkan dengan sistem yang seluruhnya terpusat).

Langkah pertama adalah membuat perencanaan jaringan. Investigasi ini ditujukan untuk mencari pola kerja, alur, trafik dan kemungkinan bottleneck di dalam jaringan. Selain itu investigasi ini bisa membantu kemungkinan kebutuhan di masa selanjutnya. Keputusan terhadap sistem jaringan bisa dilakukan dengan dua hal, memenuhi kebutuhan secara langsung atau memenuhi kebutuhan melalui hal yang bersifat alternatif. Dalam beberapa kondisi investasi di awal mungkin lebih besar dibandingkan dengan operasional yang ada, tapi di masa mendatang investasi maupun operasional selanjutnya bisa jauh lebih kecil. Selain kebutuhan di atas juga harus didefinisikan batasan yang ada seperti perangkat yang ada, kemampuan pengguna, kondisi lingkungan dan lain-lain. Berikutnya melakukan perancangan arsitektur jaringannya. Kegiatan ini meliputi perancangan topologi dengan tipe star, memastikan spesifikasi komputer untuk server karena harus sesuai dengan jumlah client yang saling berinteraksi. Melalui perangkat lunak NOS (Network Operating System) yang berjalan di server dan bertanggungjawab untuk memproses request, mengatur jaringan, dan mengendalikan layanan dan device ke semua workstation. NOS bisa saja merubah file system yang dipakai di Workstation secara transparan, misalnya pada sistem Novell Netware, Workstation menggunakan Windows dengan filesystem FAT dan Server menggunakan Netware File System. Setiap workstation membutuhkan aplikasi NOS client untuk dapat berkomunikasi dengan server. Aplikasi ini sering juga disebut sebagai shell, redirector, requestor atau client. Dalam penelitian ini menggunakan sistem operasi Linux Redhat 9 edisi server dengan dukungan aplikasi Samba Server dan sistem operasi Windows XP Propesional sebagai client/workstation.

Perancangan arsitektur client/server adalah merupakan bagian yang terbaik dari suatu penerapan jaringan karena jaringan ini memiliki keunggulan tersendiri dari pada hanya menggunakan jaringan untuk kebutuhan berbagi data atau perangkat keras komputer lainnya. Melalui arsitektur client/server seorang pemakai akan mendapat kemudahan dalam memakai dan pengelolaan datanya sendiri, dimana pada saat pemakai hendak mengambil datanya yang ada di server, pemakai tersebut tinggal membuka komputer dengan account yang telah diberikan maka secara otomatis data yang telah disimpan sebelumnya dapat ditampilkan dengan mudah tanpa melakukan porses apa-apa. Selain dari kemudahan dalam pengambilan data, keamanan data juga cukup terjamin dengan baik. Kondisi ini merupakan kontribusi penting dalam kinerja sistem aplikasi POS, dimana kerusakan pada satu komputer tidak akan mengakibatkan sistem tidak bekerja dengan baik, karena semua data yang tersimpan pada komputer tersebut masih dapat diambil dan diberdayakan di komputer lainnya. 
Pemakaian sistem operasi Linux redhat 9.0 dalam penelitian ini adalah pilihan alternatif dalam menentukan sistem operasi apa yang tepat untuk sistem operasi pada komputer server. Bila dibandingkan dengan Windows, Linux memang baru dikenal oleh kalangan masyarakat, namun dalam pemakaiannya terutama untuk komputer server, Linux memiliki keunggulan, kehandalan dan tahan terhadap serangan virus. Disamping itu spesifikasi hardware yang dibutuhkan juga relatif lebih ringan bila dibandingkan dengan sistem operasi lain seperti windows untuk menjalankan aplikasi yang sama. Kelebihan yang utama adalah sistem operasi Linux bersifat free licence. Kenyataan ini dapat membuat biaya pemeliharaan sistem menjadi lebih murah dan kinerjanya juga lebih stabil. Selain itu, distro RedHat 9.0 pada umumnya mudah didapat, baik itu berupa software download gratis dari internet ataupun yang menjadi penyerta dalam sebuah buku panduan atau petunjuk praktis yang membahas mengenal sistem operasi Linux.

Untuk proses instalasi sistem operasi ke dalam komputer yang dijadikan sebagai Server menggunakan Linux Redhat 9.0 Edisi Server. Pada tahap instalasi ini, kegiatan pertama yang harus dilakukan adalah melakukan Install Linux dalam modus grafik; jadikan instalasi Redhat sebagai Server; buat tiga partisi, yaitu boot, root dan swap; pada bagian setting TCP/IP tentukan IP address dengan 192.168.0.254 dan subnet mask 255.255.255.0; berikut ketikkan "LinuxServer" pada bagian netbios name; selanjutnya pada bagian paket instalasi, tandai pilihan Windows File Server. Setelah tahap instalasi Linux selesai, maka langkah selanjutnya adalah melakukan perubahan pada konfigurasi Linux dengan tujuan agar sistem operasi Linux ini bisa dijadikan sebagai komputer Server. Berikut adalah langkah-langkah dalam mengkonfigurasi Linux, yaitu masuk ke consol dengan account root; ketikkan perintah \# netconfig; aturlah setting IP; uninstall paket samba (samba, samba-client, samba-common) bawaan dari Linux; install samba-Server, samba-Client dan samba-common versi 3.0.rpm; lalu jalankan service dan tanda pada pilihan smb.

Kegiatan selanjutnya adalah agar Samba dapat digunakan sebagai PDC (Primary Domain Controller) ada beberapa langkah konfigurasi yang harus dilakukan. Sebelumnya pastikan bahwa dalam satu domain hanya terdapat satu PDC. Apabila telah terdapat PDC Windows maka anda harus mematikannya terlebih dahulu agar tidak konflik dengan PDC Samba. Setelah Samba dikonfigurasi sebagai PDC maka samba telah siap difungsikan sebagai Domain Controller layaknya Anda memiliki Windows 2000 Server/NT. Langkah selanjutnya adalah membuat account linux dan account samba yang akan bergabung ke domain. Setelah Server Samba dikonfigurasi sebagai PDC maka langkah selanjutnya adalah menggabungkan klien Windows ke domain Linux. Cara konfigurasi ini sama dengan apabila menggunakan Windows NT/2000 Server. Dalam hal ini menggunakan Client Windows XP Professional dan ini dapat juga digunakan untuk Windows 2000 versi Professional dan Server, serta Windows Xp versi Home.

Untuk memodelkan perancangan sistem aplikasi POS dengan arsitektur client/server berbasis Linux dan Windows yang dihasilkan dilakukan dengan memfokuskan kepada diagram use case, activity, sequence, dan class. Melalui diagram use case untuk menunjukkan fungsionalitas suatu sistem atau kelas dari cara sistem berinteraksi dengan pemakai sistem. Perancangan proses fungsionalitas yang terjadi dalam perancangan aplikasi minimarket ini dapat dilihat pada gambar 3 . 


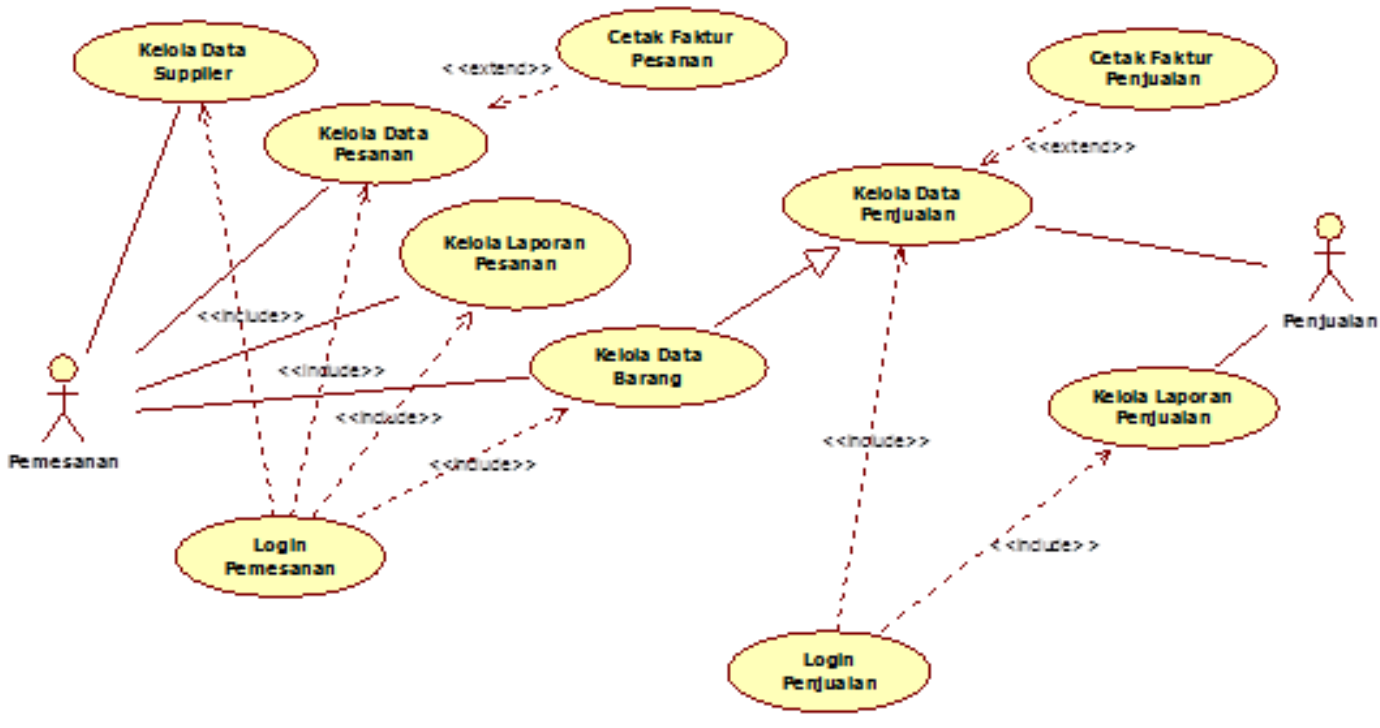

Gambar 3. Diagram Use Case Pengelolaan Konten Aplikasi POS

Pemodelan dengan diagram activity menggambarkan berbagai alur aktivitas dalam sistem yang sedang dirancang, bagaimana masing-masing alur berawal, keputusan yang mungkin terjadi, dan bagaimana sistem ini bekerja dan berakhir. Diagram ini merupakan state diagram khusus, di mana sebagian besar state adalah action dan sebagian besar transisi ditrigger oleh selesainya state sebelumnya. Oleh karena itu, diagram activity tidak menggambarkan perilaku internal sebuah sistem secara eksak, namun lebih menggambarkan proses-proses dan jalur-jalur aktivitas dari level atas secara umum dengan maksud agar mudah dipahami. Setiap kegiatan mencerminkan stimulus yang terjadi pada sistem. Gambar 4, 5 dan 6 berikut ini memperlihatkan diagram activity untuk kebutuhan mengelola data barang, data supplier, dan menampilkan data transaksi penjualan.

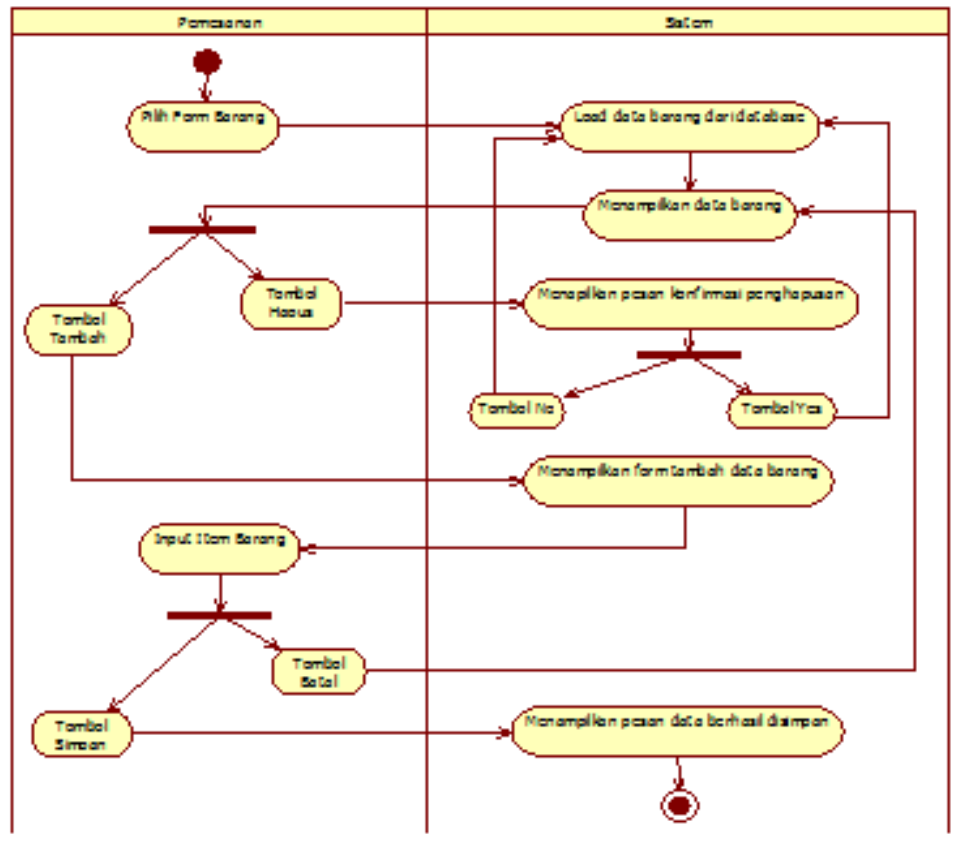

Gambar 4. Diagram Activity Mengelola Data Barang 


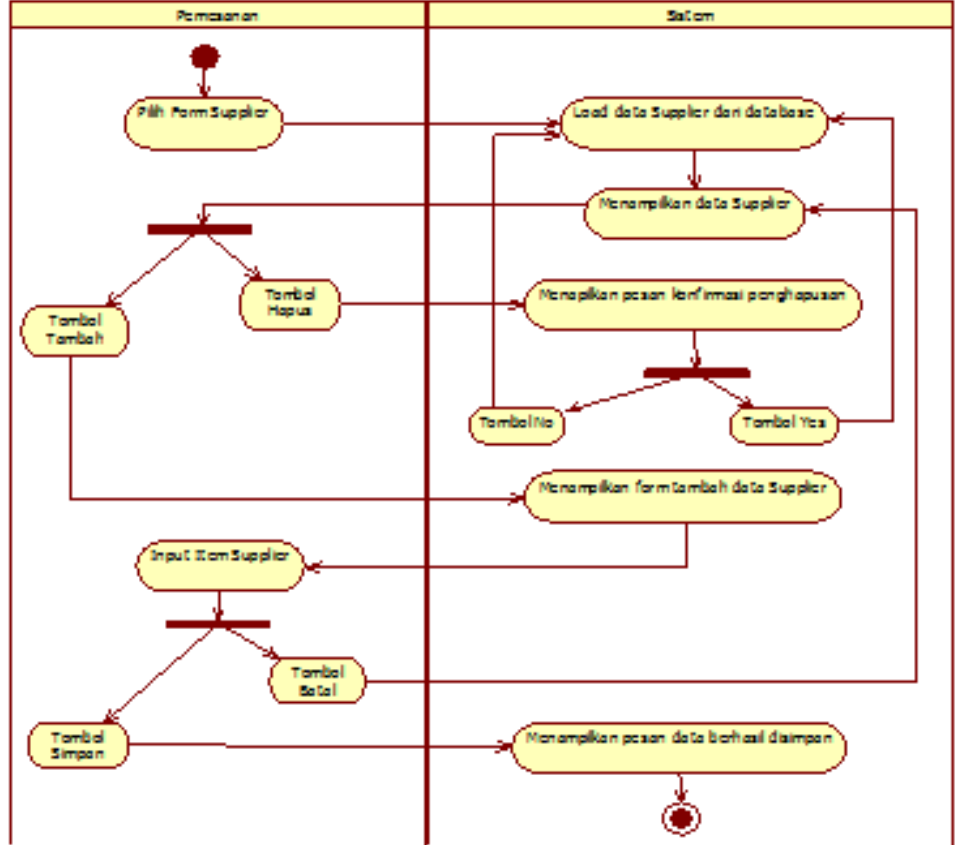

Gambar 5. Diagram Activity Mengelola Data Supplier

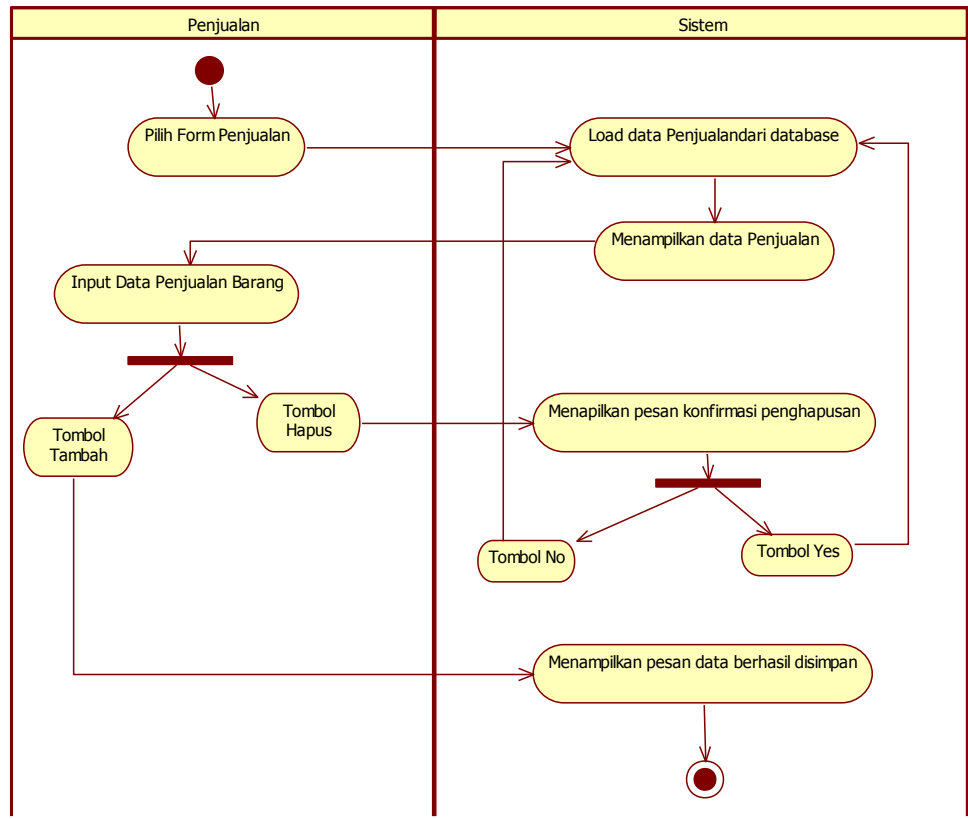

Gambar 6. Diagram Activity Data Transaksi Penjualan

Sementara diagram sequence untuk menggambarkan skenario atau rangkaian langkahlangkah dari aplikasi minimarket yang dilakukan sebagai respons dari sebuah event untuk menghasilkan hasil keluaran tertentu sesuai proses bisnisnya masing-masing. Diawali dari apa yang men-trigger aktivitas tersebut, proses dan perubahan apa saja yang terjadi secara internal dan output apa yang dihasilkan bagi pihak manajemen. Berikut ini memperlihatkan diagram sequence transaksi penjualan ritel dan laporan penjualan, seperti dapat dilihat pada gambar 7 dan 8 . 
Citec Journal, Vol. 1, No. 2, Februari 2014 - April 2014

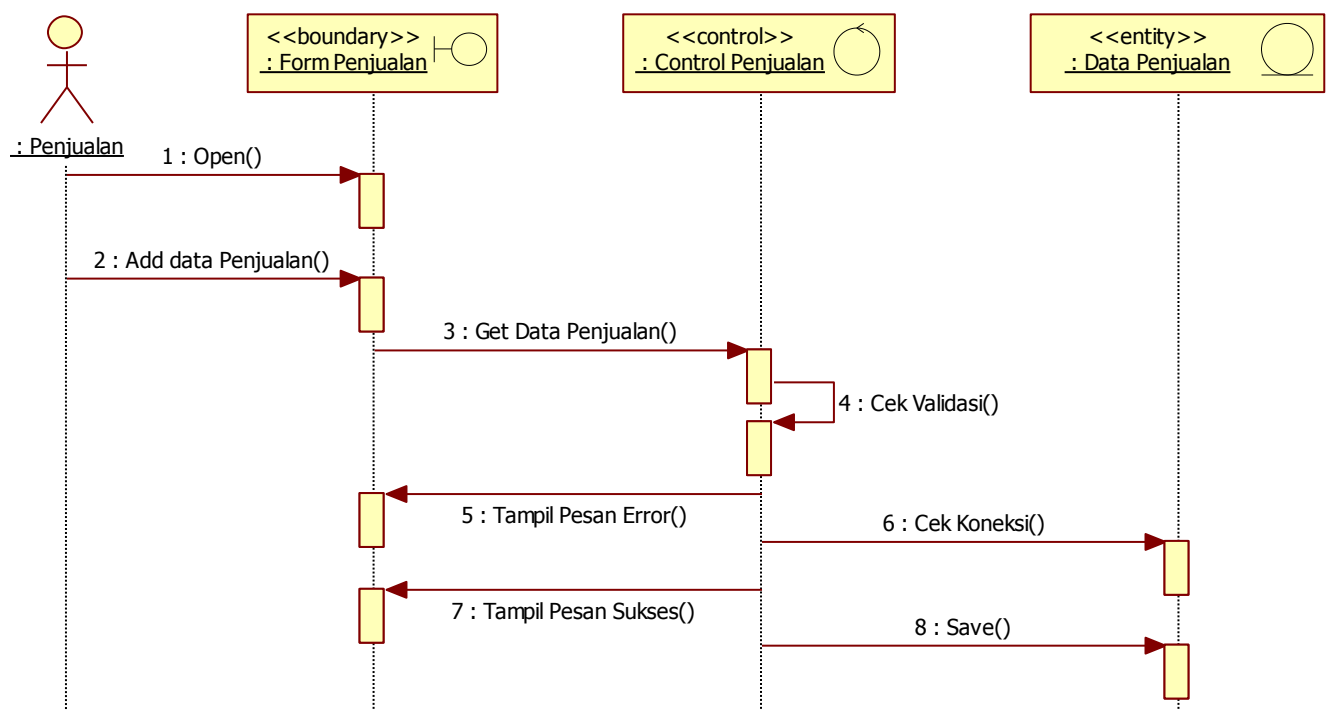

Gambar 7. Diagram Sequence Transaksi Penjualan ritel

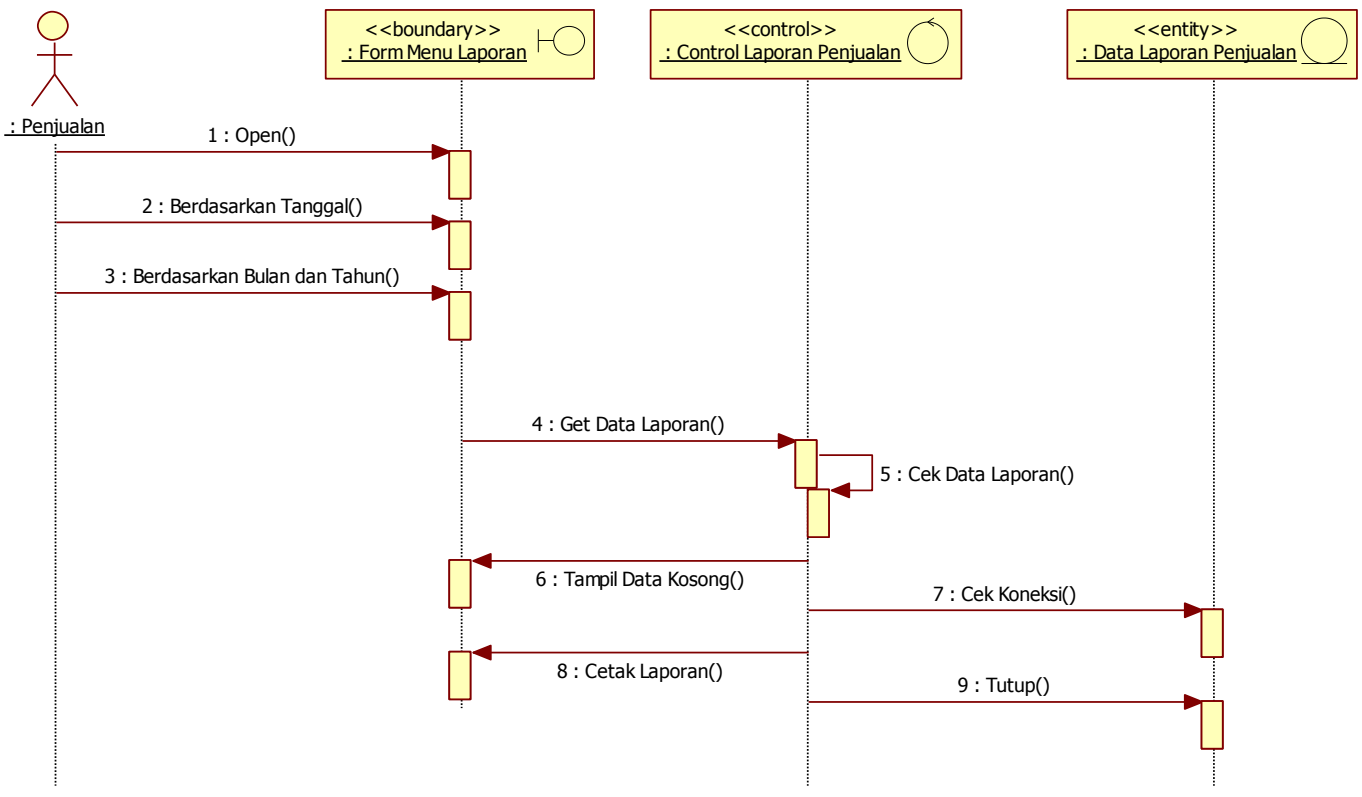

Gambar 8. Diagram Sequence Laporan Penjualan

Berikut adalah diagram class yang digunakan untuk menampilkan beberapa kelas serta paket-paket yang ada dalam sistem/perangkat lunak yang sedang digunakan. diagram class juga memberikan gambaran (diagram statis) tentang sistem/perangkat lunak dan relas-relasi yang ada didalamnya. Diagram class dan diagram hubungan entitas pada aplikasi minimarket dapat dilihat pada gambar 9 berikut ini. 

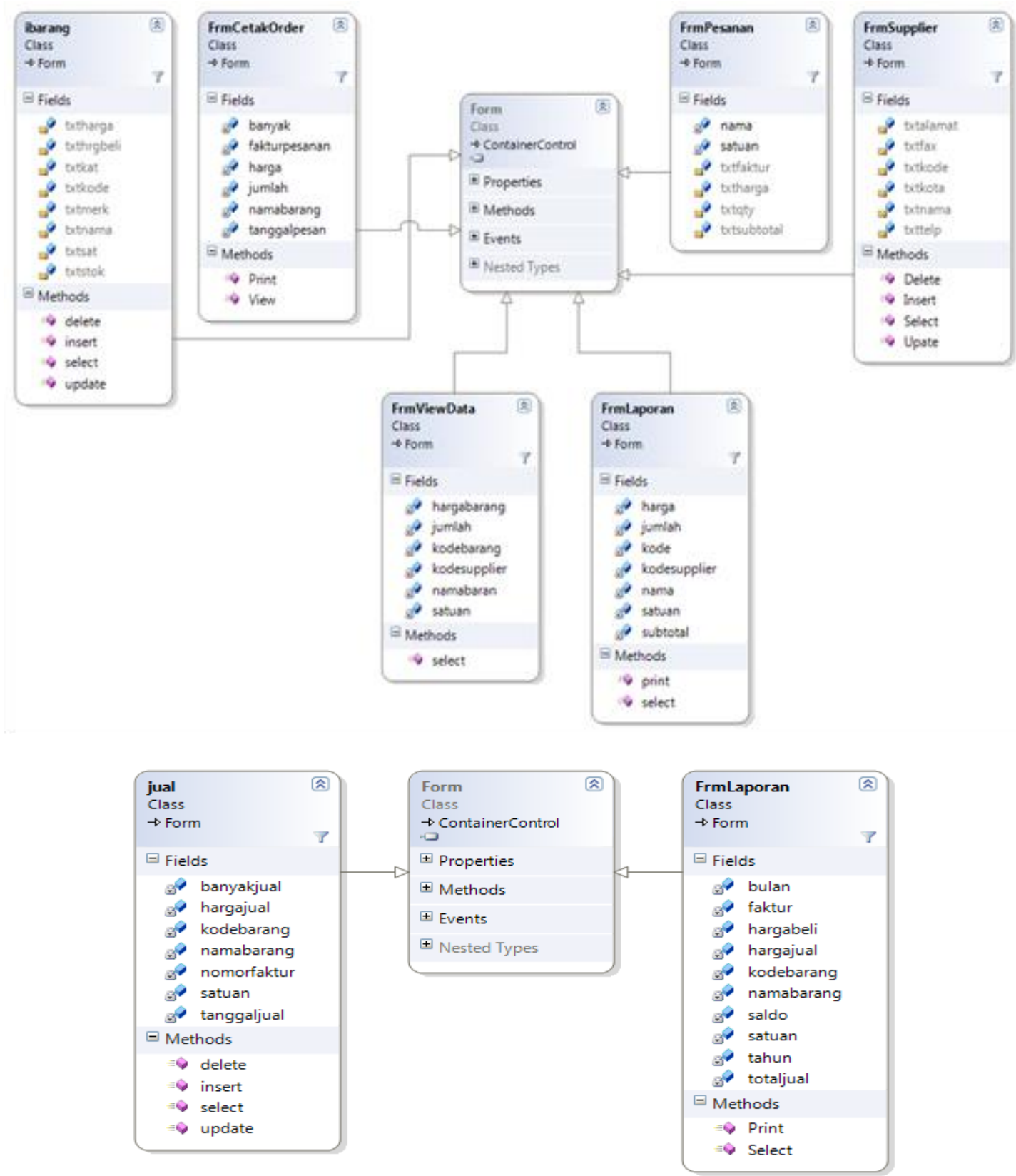

Gambar 9. Diagram Class Transaksi Penjualan

Selanjutnya dalam perancangan detilnya mencakup database, antarmuka dan sejumlah laporan bagi pihak manajemen. Pokok pemikiran dalam merancang database adalah bagaimana merancang database sehingga dapat memenuhi kebutuhan saat ini dan kemudahannya untuk dikembangkan dimasa yang akan datang. Perancangan model konseptual perlu dilakukan disamping perancangan secara phisik. Pada perancangan konseptual, digunakan beberapa konsep pendekatan relasional namun tidak berarti konsep ini harus diimplementasikan ke model relasional saja tetapi juga apat dengan model Hirarchi dan model Network. Model konseptual mengkombinasikan beberapa cara untuk memproses data dan untuk beberapa aplikasi. Model konseptual tidak tergantung aplikasi tertentu dan tidak tergantung DBMS, Hadware yang digunakan. Pada perancangan model konseptual tinjauan dilakukan pada struktur data dan relasi antar file menggunakan model dan relasional dalam bentuk diagram hubungan entitas seperti pada gambar 10 berikut ini. 


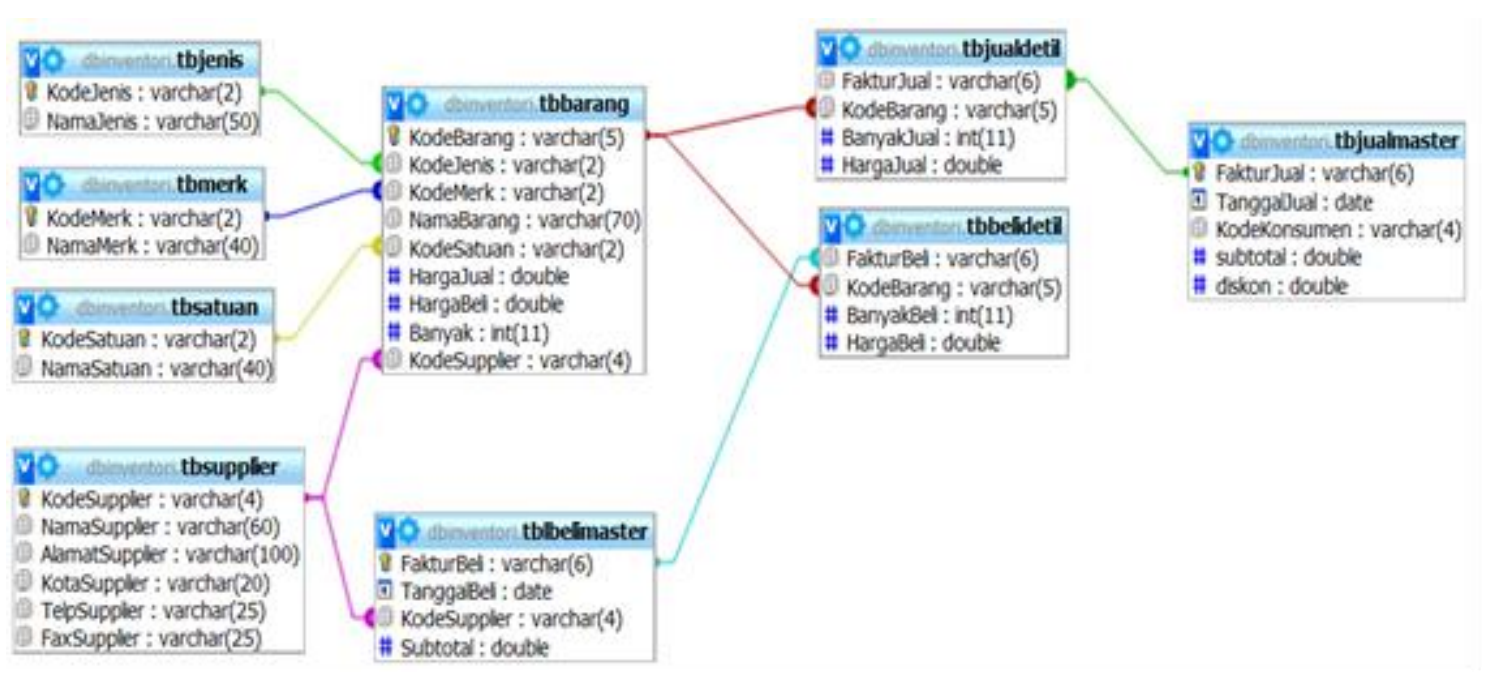

\section{Gambar 10. Diagram Hubungan Entitas}

Dalam merancang antarmuka merupakan bagian yang paling penting dari merancang sistem. Biasanya hal tersebut juga merupakan bagian yang paling sulit karena dalam merancang antarmuka harus memenuhi tiga persyaratan: sebuah antarmuka harus sederhana, sebuah antarmuka harus lengkap, dan sebuah antarmuka harus memilki kinerja yang cepat. Alasan utama mengapa antarmuka sulit untuk dirancang adalah karena setiap antarmuka adalah sebuah bahasa pemrograman yang kecil: antarmuka menjelaskan sekumpulan objek-objek dan operasioperasi yang bisa digunakan untuk memanipulasi objek.

Dalam perancangan aplikasi modul transaksi penjualan diawali dengan modul yang berisikan kegiatan penginputan data supplier, data barang, transaksi penjualan dan laporan yang dibutuhkan. Untuk modul transaksi penjualan meliputi perancangan form login, dimana form login ini dipergunakan untuk memberikan hak akses kepada pengguna. Perancangan form pengelolaan data barang untuk menambah, merubah, menghapus dan mencari data. Perancangan form supplier dipergunakan untuk mengelola data supplier dari setiap barang yang dibeli. Memiliki fasilitas menampilkan informasi sesuai kebutuhan manajemen dan unit kerja lainnya. Sementara modul penjualan berisikan fitur untuk mengelola data konsumen, penjualan dan laporan penjualan barang ritel. Untuk form login penjualan juga memiliki hak akses tertentu untuk mengontrol keamanan sistem. Gambar 11, 12 dan 13 memperlihatkan form faktur penjualan, struk penjualan dan mutasi pengontrolan persediaan barang.

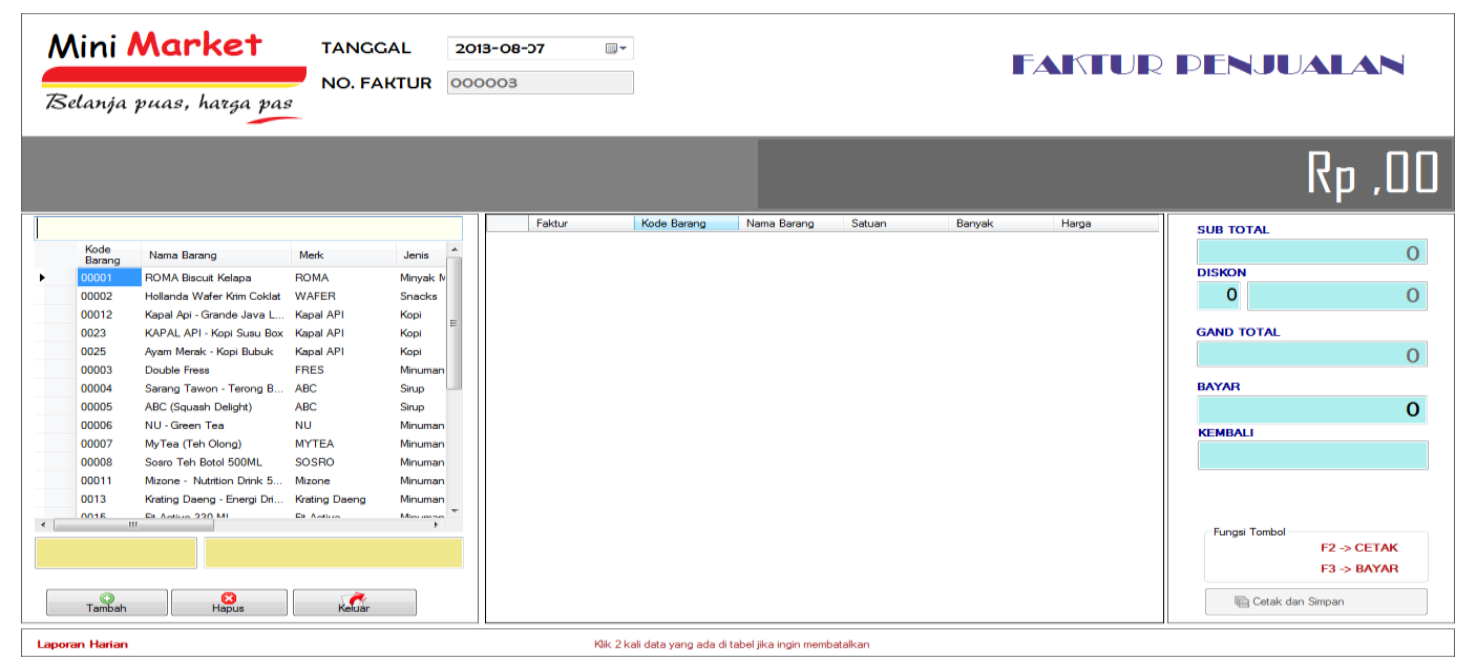

Gambar 10. Form Faktur Penjualan Barang 


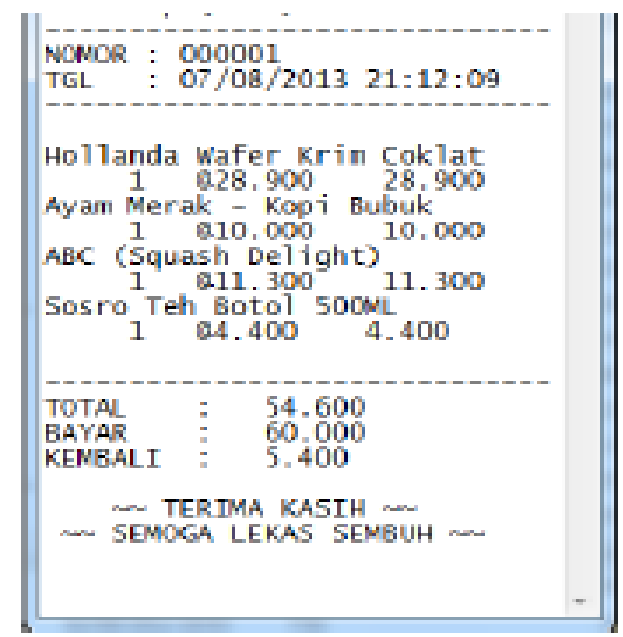

Gambar 11. Form Struk Penjualan Barang

\begin{tabular}{|c|c|c|c|c|c|c|c|c|}
\hline Kode Earang & Nons Barang & Stron & Neok & veris & Harga tod & Hage Bel & Sok & - Supples \\
\hline 00004 & Sarang Tawon - Terong Belanda Sirup & 8ctol & $A B C$ & Sins & 14900 & 16000 & 14 & A Trex livs Toma \\
\hline$\infty 023$ & KAPNL API-Kosi Susu Box & Bungious & Kosos AFI & Kosi & 4300 & 3500 & 11 & A Tectgate hotonesis Dris toros \\
\hline 00005 & ABC (Squash Deligte) & Boct & ABC & $\sin \theta$ & 11300 & 11000 & 11 & Tolo Waypo \\
\hline 00005 & NU. Geen Tes & Boctol & NW & Nouman & 8000 & 7200 & 11 & Pr Lbeya Bum Vegstana \\
\hline 00001 & ROMh Becut Keleps & Aungous & RONA & Mnyak Mskan & 6000 & 5000 & 10 & A. To f N Nusa Tans \\
\hline 00002 & Holonds Wuser Ken Cokla & Aungious & WAFER & Snadks & 28980 & 28000 & 10 & Toko Wiaya \\
\hline 00012 & Kapal Aa - Grande tova Late & Angkus & Kaps AFI & Kosi & 12450 & 11450 & 9 & Crubeya Bon Vegserso \\
\hline 0018 & VRO-Ar Mrus Botal $600 \mathrm{ML}$ & Batol & NTO & Whimen & 1000 & 700 & 9 & P Techgate holonesin Divs Agoss \\
\hline 0020 & Lautsn Penyegr $320 \mathrm{ML}$ & Botd & Ksio Tiga & Mrumen & 400 & 480 & 9 & Qr Lbsa Bum Vegtans \\
\hline 0024 & Naran $570 \mathrm{ML}$ & 8ctol & Maran & Sins & 16300 & 14000 & 9 & Toko Weara Rasa \\
\hline
\end{tabular}

Gambar 12. Form Mutasi Pengontrolan Persediaan Barang

\section{KESIMPULAN}

Berdasarkan hasil kajian dan pembahasan, dapat disimpulkan perancangan aplikasi POS untuk minimarket Citra Niaga sudah dapat memberikan informasi mengenai sejumlah transaksi penjualan ritel melalui arsitektur client/server. Untuk client menggunakan windows XP Profesional dan servernya menggunakan sistem operasi Linux Redhat versi 9.0. Dalam mempercepat dan kompatibel dengan perangkat yang ada. Ketersediaan informasi mengenai persediaan barang sudah dapat diperoleh seiring dengan proses perekaman data transaksi penjualan sehingga memudahkan kasir dalam penjualan barang. Pengelolaan data barang juga menjadi lebih akurat karena adanya informasi antar proses bisnis yang saling berkaitan satu dengan lainnya. Perancangan aplikasi POS ini memiliki sejumlah fitur-fitur dimana dapat mengelola data barang menjadi lebih cepat dan keakuratan informasi menjadi lebih terjamin, memudahkan pencarian produk tertentu, lansung menerbitkan faktur penjualan, penanganan mutasi persediaan menjadi lebih optimal, menghasilkan struk penjualan dan sejumlah laporan penjualan ritel yang berkaitan dengan proses bisnis dalan pengelolaan transaksi sehari-hari. 


\section{SARAN}

Untuk dapat memberikan hasil yang lebih maksimal, pemanfaatan aplikasi POS ini tidak hanya memiliki integrasi dengan proses bisnis kasir, penjualan dan persediaan dalam gudang saja. Namun lebih baik memiliki integrasi informasi dengan proses bisnis akuntansi dan keuangan juga dan bersifat menyeluruh sehingga mempermudah pengawasan dan administrasi menyiapkan laporan keuangan perusahaan.

\section{DAFTAR PUSTAKA}

[1] Anonymous, 1999, The Integration of Point of Sale, Nation's Restaurant News, Nov 1, 1999; 33,34; ProQuest Agriculture Journals

[2] Turban, E., Volonino, L., 2010, Information Technology for Management: Transforming Organizations in the Digital Economy, Seventh Edition, John Wiley \& Sons, Inc., United State.

[3] Connolly, T., Begg, C., 2010, Database System: A Practical Approach to Design, Implementation, and Management, Fifth Edition, Addison Wesley, USA.

[4] Pressman, R. S., 2010, Software Engineering: A Practitioner's Approach, Seventh Edition, McGraw-Hill Inc., New York.

[5] Setiawan, E., Suryana, E., 2006, Aplikasi Terintegrasi Toko Swalayan, Jurnal Sistem Informasi UKM, Vol 1, No1, hal 17-26.

[6] Ginting, I. A. R., 2011, Rancangan \& Implementasi Point of Sales (POS) Berbasis Web pada Distro Previous, Skripsi, Progam Studi Sistem Informasi STMIK AMIKOM Yogyakarta. 